\title{
ANALISIS RASIO PROFITABILITAS DAN LIKUIDITAS TERHADAP STRUKTUR MODAL PADA PERUSAHAAN ASURANSI YANG TERDAFTAR DI BURSA EFEK INDONESIA
}

\author{
Yosua Anggun Febrianto ${ }^{1)^{*}}$, Ampauleng ${ }^{2)}$, Herman Sjahruddin ${ }^{3)}$ \\ 1,2,3) Manajemen Keuangan, Sekolah Tinggi Ilmu Ekonomi Makassar Bongaya \\ Email: $\underline{\text { Joshuafebry26@gmail.com }}{ }^{1)}$, aampauleng@ymail.com ${ }^{2}$, herman.sjahruddin@ @mail.com $^{3)}$
}

\begin{abstract}
Abstrak
Studi ini bertujuan untuk menguji efek profitabilitas dan likuiditas dalam meningkatkan struktur modal perusahaan asuransi di Bursa Efek Indonesia periode 2014-2018. Populasi pada penelitian ini terdiri dari 15 perusahaan dan penarikan sampel yang dilakukan menggunakan metode purposive sampling. Sampel yang digunakan sebanyak 10 perusahaan asuransi, terdapat 5 diantaranya dinyatakan tidak memenuhi kriteria. Alat analisis yang digunakan adalah analisis regresi liniear berganda yang bertujuan untuk menguji kembali pengaruh profitabilitas dan likuiditas terhadap struktur modal pada dengan menggunakan Statistical Package for the Social Sciences Vers. 25. Hasil penelitian menunjukkan bukti bahwa profitabilitas (ROA) dan likuiditas (CR) memberikan efek negatif signifikan dalam meningkatkan struktur modal.
\end{abstract}

Keywords: struktur modal, profitabilitas, likuiditas 


\section{PENDAHULUAN}

Struktur modal menjadi issu penting dalam literasi manajemen keuangan, struktur modal yang optimal bisa dilakukan menggunakan cara adanya keseimbangan yang optimal antara sumber dana berdasarkan pada perusahaan asal maupun asal dana menurut pihak luar perusahaan. struktur modal perusahaan merupakan salah satu faktor yang mendasar perusahaan yang meliputi keputusan finansial yang berkaitan menggunakan komposisi utang jangka panjang juga utang jangka pendek berdasarkan suatu perusahaan (Nawang dkk., 2016).

Kondisi serupa juga berlaku pada perusahaan Sektor Keuangan Sub-sektor Asuransi merupakan bagian dari perusahaan jasa yang berada pada sektor keuangan yang terdaftar di Bursa Efek Indonesia (BEI). Menurut Otoritas Jasa Keuangan (OJK), perusahaan asuransi merupakan suatu lembaga yang menyediakan segala macam polis asuransi yang dapat melindungi seseorang atau nasabah yang bergabung dengannya dari berbagai macam resiko dengan memegang sejumlah polis asuransi (www.ojk.go.id, diunduh 03 Februari 2020).

Di Indonesia pada awal Tahun 2020 terjadi ketidak percayaan masyarakat pada perusahaan asuransi, seperti yang dialami Asuransi Jiwasraya dan Asuransi Angkatan Bersenjata Republik Indonesia (ASABRI). Ketidak percayaan tersebut terjadi karena rendahnya akuntabilitas pelaporan keuangan perusahaan yang diilakukan perusahaan asuransi tersebut. Seharusnya sebuah perusahaan memberikan sinyal kepada pengguna laporan keuangan (Signalling theory). Manajer menjadi pengelola perusahaan lebih banyak mengetahui fakta internal dan prospek perusahaan dimasa yang akan dating dibandingkan pemilik (investor/kreditur), oleh karena itu menjadi pengelola, manajer berkewajiban memberikan sinyal mengenai kondisi perusahaan kepada pemilik (Ross, 1977; dalam Rachman, 2018; Harris, dkk., 2020).

Salah satu pertanda (signal) yang dapat diperoleh investor dan kreditur adalah struktur modal yang proporsional (optimal). bahwa untuk memilih struktur modal optimal harus memperhatikan kapasitas hutang perusahaan yaitu proporsi maksimum menurut hutang yang bisa dimasukkan dalam struktur modal dan masih mempertahankan biaya modal terendah Dalam memilih struktur modal yang optimal diperlukan usaha adanya keseimbangan yang optimal antara asal dana dari dalam perusahaan maupun sumber dan dari pihak luar perusahaan (Keown dkk.,2011).

Perbaikan pada komposisi struktur modal, untuk modal sendiri dapat diperoleh melalui profitabilitas perusahaan. Besaran profitabilitas akan mempengaruhi keputusan manajemen untuk melakukan pendanaan dari luar atau tidak, juga akan mempengaruhi keputusan manajemen menggunakan dana dalam operasionalnya (Murhadi 2011). Teori signaling menjelaskan bahwa informasi Perusahaan yang memiliki profitabilitas yang tinggi serta berhasil membukukan keuntungan yang terus semakin tinggi akan memperlihatkan bahwa perusahaan berkinerja baik, sehingga akan menciptakan respon yang positif dalam pemegang saham dan menciptakan harga saham perusahaan semakin tinggi.

Profitabilitas yang tinggi juga menunjukkan prospek perusahaan yang baik, sehingga akan membangun sentimen positif bagi pemegang saham dan nilai perusahaan akan semakin tinggi (Sujoko dan Soebiantoro, 2007: 43; dalam Ramadhani, 2013; Lorenza dkk., 2020). Pemilihan variable profitabilitas dilakukan dengan alasan profitabilitas perusahaan dapat menunjukan seberapa mampu perusahaan dalam menghasilkan laba, baik dari penjualan yang ada maupun dari aset total yang dimiliki (Gumanti,2011).

Selain profitabililitas terdapat juga faktor lainnya, yaitu faktor Likuiditas atau faktor internal yang dapat mempengaruhi struktur modal. Semakin tinggi likuiditas, maka semakin tinggi kemampuan perusahaan untuk membayar kewajiban jangka pendeknya, sehingga memberikan signal positif pada para investor bahwa perusahaan itu adalah perusahaan yang sehat. Pemilihan likuiditas disebabkan karena likuiditas merupakan suatu indikator yang dapat menunjukan kondisi perusahaan dalam membayar semua kewajiban jangka pendeknya yang telah jatuh tempo. Hasil penelitian terdahulu membutikan bahwa likuiditas berpengaruh positif dan signifikan terhadap struktur modal (Irdiana, 2016; 
Bhawa, 2015). Temuan yang berbeda ditemukan pada penelitian yang dilakukan Deviani (2018) ; Saputri dkk., (2020) bahwa likuiditas berpengaruh negatif dan signifikan terhdap struktur modal.

Penjelasan terhadap teori signal juga ditemukan pada hasil penelitian yang dilakukan Nugroho (2014), bahwa profitabilitas berpengaruh positif signifikan terhadap struktur modal. Temuan yang berbeda ditemukan pada penelitian yang dilakukan (Wahyuni dan Suryantini, 2014: Siahaan dkk., 2020) bahwa profitabilitas berpengaruh negatif dan signifikan terhadap struktur modal perusahaan. Perbedaan lainnya ditunjukkan pada studi Saputri dkk., (2020) bahwa profitabilitas memberikan efek positif namun tidak signifikan dalam meningkatkan struktur modal.

Tabel 1. Debt to equity ratio (DER) perusahaan Sub-sektor Asuransi Tahun 2017- 2018

\begin{tabular}{clccc}
\hline \multicolumn{5}{c}{ Nebt to equity } \\
No. & Emiten & \multicolumn{2}{c}{ ratio $(\mathrm{DER})$} & Perubahan \\
& & 2017 & 2018 & \\
\hline 1. & ABDA & 1.16 & 1.05 & -0.11 \\
2. & AHAP & 1.09 & 0.81 & -0.28 \\
3. & AMAG & 1.10 & 1.44 & 0.34 \\
4. & ASBI & 1.76 & 1.88 & 0.12 \\
5. & ASDM & 2.64 & 2.83 & 0.19 \\
6. & ASJT & 1.11 & 1.20 & 0.09 \\
7. & ASMI & 0.89 & 0.71 & -0.18 \\
8. & ASRM & 2.98 & 2.93 & -0.05 \\
9. & JMAS & 0.45 & 0.5 & 0.05 \\
10. & LPGI & 1.21 & 1.46 & 0.25 \\
11. & MREI & 1.12 & 1.23 & 0.11 \\
12. & MTWI & 1.24 & 1.68 & 0.44 \\
13. & PNIN & 0.18 & 0.16 & -0.02 \\
14. & TUGU & 1.29 & 1.35 & 0.06 \\
15. & VINS & 0.34 & 0.32 & -0.02 \\
Rata-rata & 1.24 & 1.30 & 0.07 \\
\hline Sum & Mer & \\
\hline
\end{tabular}

Sumber :www.idx.co.id, data di olah, 2020

Tabel tersebut menunjukan bahwa perusahaan sub- sektor asuransi yang terdaftar pada Bursa Efek Indonesia sebanyak 15 emiten, perkembangan nilai debt to equity ratio tahun 2017-2018 mengalami perubahan rata - rata sebesar 0,07. Perubahan yang menunjukkan kenaikan, sehingga menjadi alasan dilakukannya penelitian ini.

Berdasarkan latar belakang dan fakta empiris diatas, maka peneliti sangat tertarik untuk melakukan penelitian dengan judul analisis rasio profitabilitas dan likuiditas terhadap struktur modal pada perusahaan asuransi yang terdaftar di bursa efek Indonesia dengan tujuan:

1. Untuk mengetahui pengaruh profitabilitas terhadap struktur modal pada perusahaan asuransi yang terdaftar di bursa efek Indonesia

2. Untuk mengetahui pengaruh likuiditas terhadap struktur modal pada perusahaan asuransi yang terdaftar di bursa efek Indonesia

\section{TINJAUAN PUSTAKA}

Manajemen keuangan menjelaskan keseluruhan aktivitas perusahaan yang berhubungan dengan usaha mendapatkan dana yang diperlukan dengan biaya yang minimal dan syarat-syarat yang paling menguntungkan beserta usaha untuk menggunakan dana tersebut se-efisien mungkin (Bambang Riyanto, 1995; dalam Ni luh Gede Erni Sulindawati, dkk, $2017: 3$ ).

Profitabilitas merupakan tingkat keuntungan bersih yang mampu diraih oleh perusahaan pada saat menjalankan operasinya. Profitabilitas suatu perusahaan dapat diukur dengan rasio profitabilitas. Rasio profitabilitas merupakan rasio untuk menilai kemampuan perusahaan dalam mencari keuntungan (kasmir 2017: 196). Salah satu rasio atau alat ukur yang digunakan untuk mengetahui tingkat profitabilitas perusahaan adalah Return On Assets (ROA). Dalam hal ini Return On Assets diukur dengan perbandingan antara laba bersih sesudah pajak dengan total aktiva perusahaan (Lukas Setia, 2008: 417; dalam Santoso, 2016). Untuk menghitung ROA yaitu dengan menggunakan rumus sebagai berikut:

$$
\text { Return On Asset }=\frac{\text { Laba bersih setelah pajak }}{\text { Total asset }}
$$

Rasio Likuiditas merupakan rasio yang digunakan untuk mengukur kemampuan likuiditas jangka pendek perusahaan dengan melihat besarnya aktiva lancar relatif terhadap utang lancarnya. (Mamduh M. Hanafi dan Halim, 2014: 37). Dalam penelitian ini 
likuiditas diukur dengan rasio current ratio (CR) dalam hal ini current ratio diukur dengan perbandingan antara aktiva lancar dan hutang lancar (kasmir 2012:110). Untuk menghitung $\mathrm{CR}$ yaitu dengan menggunakan rumus sebagai berikut:

$$
\text { Current Ratio }=\frac{\text { Aktiva lancar }}{\text { Utang lancar }}
$$

struktur modal merupakan komposisi saham biasa, saham preferen, dan berbagai kelas seperti itu, laba yang ditahan, dan utang jangka panjang yang dipertahankan oleh kesatuan usaha dalam mendanai aktiva (Fahmi,2014:175). Dalam penelitian ini struktur modal diukur dengan rasio Debt to Equity Ratio (DER). Debt to Equity Ratio (DER) merupakan rasio yang digunakan untuk mengukur tingkat penggunaan utang terhadap total ekuitas perusahaan. Berikut rumus untuk menghitung struktur modal berdasarkan rasio Debt to Equity Ratio (DER) menurut (Bambang Riyanto 2001 : 333; dalam Santoso, 2016):

Debt to Equity Ratio $=\frac{\text { Total Utang }}{\text { Modal Sendiri }}$

\section{METODE PENELITIAN}

Berdasarkan jenisnya, penelitian ini tergolong dalam pendekatan kuantitatif yang menggunakan angka-angka sebagai data penelitian, pendekatan dalam penelitian ini adalah pendekatan cross sectional (pengamatan sesaat) atau penelitian dengan melakukan pengukuran atau pengamatan pada saat bersamaan atau sekali waktu (Hidayat, 2007 dalam kusumo wardani, 2014).

Analisis statistik dalam penelitian ini menggunakan pengujian deskriftif statistic dan analisis regresi berganda yang dilakukan melalui SPSS versi 25.

Berdasarkan metode analisis tersebut, Hipotesis yang akan di uji yaitu:

$\mathrm{H}_{1} \quad$ :Profitabilitas berpengaruh negative dan signifikan terhadap Struktur Modal

$\mathrm{H}_{2}$ :Likuiditas berpengaruh negative dan signifikan terhadap Struktur Modal.

\section{HASIL DAN PEMBAHASAN}

Upaya untuk menunjukkan data secara deskriptif diperlihatkan pada tabel berikut:

Tabel 2. Statistic deskriptif

\begin{tabular}{|c|c|c|c|c|}
\hline \multicolumn{2}{|c|}{ Deskriptif } & ROA & $\mathrm{CR}$ & DER \\
\hline \multirow[t]{2}{*}{$\mathrm{N}$} & Valid & 50 & 50 & 50 \\
\hline & Missing & 0 & 0 & 0 \\
\hline \multicolumn{2}{|c|}{ Mean } & 6.0333 & 4.7245 & 4.8441 \\
\hline \multicolumn{2}{|c|}{ Median } & 6.1159 & 4.8402 & 4.8675 \\
\hline \multicolumn{2}{|c|}{ Std. Deviation } & .61463 & .52769 & .78625 \\
\hline \multicolumn{2}{|c|}{ Range } & 2.67 & 2.50 & 3.45 \\
\hline \multicolumn{2}{|c|}{ Minimum } & 4.17 & 3.04 & 2.77 \\
\hline \multicolumn{2}{|c|}{ Maximum } & 6.85 & 5.54 & 6.22 \\
\hline
\end{tabular}

Sumber: Output SPSS Ver.25, 2020

Hasil analisis statistik deskriptif masingmasing variabel independen dan variabel dependen dapat diketahui nilai rata-rata (mean) dan standar deviasi serta nilai maksimum dan minimum. Dalam hasil pengujian statistik deskriptif, Variabel ROA yang memperoleh nilai minimum sebesar 4.17 dan nilai maximum 6.85 dengan rata-rata (mean) 6.0333 pada standar deviasi 0.61463 nilai rata-rata (mean) lebih besar dari standar deviasi yaitu $6.0333>0.61463$. hal ini menunjukkan bahwa data terdistribusi dengan baik.

Variable CR memperoleh nilai minimum sebesar 3.04 dan nilai maximum 5.54 dengan rata-rata (mean) 4.7245 pada standar deviasi 0.52769 nilai rata-rata (mean) lebih besar dari standar deviasi yaitu $4.7245>0.52769$. hal ini menunjukkan bahwa data terdistribusi dengan baik. Data pada variable DER Imemperoleh nilai minimum sebesar 2.77 dan nilai maximum 6.22 dengan nilai rata-rata (mean) sebesar 4.8441 pada standar deviasi sebesar 0.78625 nilai rata-rata (mean) lebih besar dari standar deviasi yaitu $4.8441>0.78625$. hal ini menunjukkan bahwa data terdistribusi dengan baik.

\section{Uji Asumsi Klasik ( Uji BLUE (best, linear, unbiased, estimated))}

Berikut ini adalah hasil dari uji asumsi klasik :

1. Uji Normalitas 
Tabel 3. Hasil Uji Normalitas

\begin{tabular}{llr}
\hline & & $\begin{array}{r}\text { Unstandardiz } \\
\text {-ed Residual }\end{array}$ \\
\hline $\mathrm{N}$ & & 50 \\
\hline Normal Parameters ${ }^{\mathrm{a}, \mathrm{b}}$ & Mean & .0000000 \\
\cline { 2 - 3 } & Std. & .69804360 \\
& Deviation & \\
\hline Most Extreme & Absolute & .120 \\
\cline { 2 - 3 } Differences & Positive & .086 \\
\cline { 2 - 3 } & Negative & -.120 \\
\hline Test Statistic & & .120 \\
\hline Asymp. Sig. (2-tailed) & & $.067^{\mathrm{c}}$ \\
\hline Sumber: Output SPSS
\end{tabular}

Sumber: Output SPSS Ver.25, 2020

Nilai test statistic $0.120>0.05$ dan Asymp. Sig. (2-tailed) sebesar 0,067>0,05. Sehingga dapat diambil kesimpulan bahwa data yang digunakan dalam penelitian ini terdistribusi normal.

\section{Uji Autokolerasi}

Tabel 4. Hasil Uji Autokolerasi

\begin{tabular}{rrrr}
\hline df1 & df2 & $\begin{array}{c}\text { Sig. F } \\
\text { Change }\end{array}$ & Durbin-watson \\
\hline 2 & 47 & .004 & 2.188 \\
\hline
\end{tabular}

Sumber: Output SPSS Ver.25, 2020

Berdasarkan hasil uji autokorelasi pada model summary menunjukkan bahwa nilai DW sebesar 2.188 , jumlah responden sebanyak 50 dan 2 variabel $\mathrm{x}$ maka diperoleh nilai $\mathrm{dL}$ sebesar 1.4625 , nilai dU sebesar 1.6283 dan nilai 4 - DU sebesar 2.3717 artinya $\mathrm{Du}<\mathrm{D}<$ 4 - Du $(1.6283>2.188<2.3717)$ maka dapat disimpulkan bahwa dalam penelitian ini tidak ada autokerelasi positif maupun negative.

3. Uji Multikolonieritas

Tabel 5. Hasil Uji Multikolonieritas

\begin{tabular}{lcc}
\hline Variabel & \multicolumn{2}{c}{ Collinearity Statistics } \\
\cline { 2 - 3 } Independen & Tolerance & VIF \\
\hline ROA & .992 & 1.008 \\
CR & .992 & 1.008 \\
\hline
\end{tabular}

Sumber: Output SPSS Ver.25, 2020
Hasil pengujian nilai Tolerance sebesar 0.992 $<1$ dan nilai VIF sebesar $=1.008<10$ sehingga dengan demikian dapat dinyatakan bahwa data hasil penelitian tidak terjadi multikoleniaritas.

4. Uji Heterokedastisitas

Tabel 6 Hasil Uji Heterokedastisitas

\begin{tabular}{|c|c|c|c|c|c|c|}
\hline \multirow{2}{*}{\multicolumn{2}{|c|}{ Model }} & \multicolumn{2}{|c|}{$\begin{array}{c}\text { Unstandardized } \\
\text { Coefficients }\end{array}$} & \multirow{2}{*}{$\begin{array}{c}\text { Standar } \\
\text { dized } \\
\text { Coeffici } \\
\text { ents } \\
\\
\text { Beta } \\
\end{array}$} & \multirow[t]{2}{*}{$\mathrm{t}$} & \multirow[t]{2}{*}{ Sig. } \\
\hline & & B & $\begin{array}{l}\text { Std. } \\
\text { Error }\end{array}$ & & & \\
\hline 1 & $\begin{array}{l}\text { (Cons } \\
\operatorname{tant})\end{array}$ & .168 & .949 & & .177 & .860 \\
\hline & ROA & .050 & .111 & .066 & .454 & .652 \\
\hline & $\mathrm{CR}$ & .009 & .130 & .010 & .067 & .947 \\
\hline
\end{tabular}

Sumber: Output SPSS Ver.25, 2020

Probability valuae variable ROA sebesar 0.652 $>0.05$ dan CR sebesar $0.947>0.05$ sehingga hasil tersebut mengindikasikan bahwa tidak terjadi heteroskedastisitas.

\section{Uji Regresi Linear Berganda}

Berikut ini hasil regresi dalam penelitian ini :

Tabel 7 Uji Regresi Linear Berganda

\begin{tabular}{|c|c|c|c|c|c|c|}
\hline \multirow{2}{*}{\multicolumn{2}{|c|}{ Model }} & \multicolumn{2}{|c|}{$\begin{array}{l}\text { Unstandardize } \\
\text { d Coefficients }\end{array}$} & \multirow{2}{*}{$\begin{array}{c}\text { Standa } \\
\text { rdized } \\
\text { Coeffi } \\
\text { cients } \\
\\
\text { Beta } \\
\end{array}$} & \multirow[t]{2}{*}{$\mathrm{t}$} & \multirow[t]{2}{*}{ Sig. } \\
\hline & & $\mathrm{B}$ & Error & & & \\
\hline \multirow[t]{3}{*}{1} & $\begin{array}{l}\text { (Const } \\
\text { ant) }\end{array}$ & 9.821 & 1.419 & & 6.919 & .000 \\
\hline & ROA & -.503 & .166 & -.393 & -3.025 & .004 \\
\hline & CR & -.411 & .194 & -.276 & -2.122 & .039 \\
\hline
\end{tabular}

Sumber: Output SPSS Ver.25, 2020

Berdasarkan tabel di atas maka diperoleh persamaan sebagai berikut:

$\mathrm{Y}=9.821-0.503 \mathrm{X}_{1}-0.411 \mathrm{X}_{2}+\varepsilon$

Dari persamaan regresi tersebut, dapat dijelaskan sebagai berikut:

1. Angka konstanta sebesar 9.821 menyatakan jika profitabilitas $\left(\mathrm{X}_{1}\right)$ 
dan likuiditas $\left(\mathrm{X}_{2}\right)$ nilainya 0 , maka struktur modal $(\mathrm{Y})$ nilainya sebesar 9.821

2. Koefisien profitabilitas $\left(X_{1}\right)$ sebesar 0.503 menyatakan bahwa setiap penambahan $1 \%$ ROA, maka akan meningkatkan struktur modal (DER) sebesar -0.503 pada saat variabel lainnya tidak berubah (konstan)

3. Koefisien CR sebesar -0.411 menyatakan bahwa setiap penambahan $1 \% \mathrm{CR}$, maka akan meningkatkan DER sebesar -0.411 pada saat variabel lainnya tidak berubah (konstan).

\section{Uji t-statistik}

a) Pengaruhprofitabilitas terhadap struktur modal

Nilai t-hitung profitabilitas sebesar -3.025 dan signifikan pada tingkat kepercayaan $(\alpha=0,05), p$-value sebesar $0,004<0,05$. Nilai $t_{\text {tabel }}$ pada $\alpha=0,05$ dan dengan derajat kebebasan $=47$ sebesar $=2.012$. Nilai $t-$ hitung $-3.025<\mathrm{t}_{\text {-tabel }}$ 2.011. memberikan bukti bahwa hipotesis yang diajukan terbukti diterma bahwa profitabilitas memberikan efek negative signifikan pada struktur modal.

b) Pengaruh likuiditas terhadap struktur modal

Nilai t-hitung likuiditas sebesar -2.122 dan signifikan pada tingkat kepercayaan $(\alpha=0,05)$, nilai $p$-value sebesar $0,039>$ 0,05 . Nilai $t_{\text {tabel }}$ pada $\alpha=0,05$ dan dengan derajat kebebasan $=49$ sehingga diperoleh $\mathrm{t}_{\text {tabel }}=2.010$. Nilai $\mathrm{t}$-hitung $-2.122<\mathrm{t}$-tabel 2.010, hasil tersebut memberikan bukti bahwa likuiditas memberikan efek negatif signifikan pada struktur modal.

Hasil tersebut dapat dibuktikan pada tabel berikut:

\begin{tabular}{ll|r|r}
\multicolumn{4}{c}{ Table 8. Hasil t-statistik } \\
\hline \multirow{2}{*}{ Model } & t-statistik & \multicolumn{1}{c}{ Sig. } \\
\hline \multirow{2}{*}{1} & (Constant) & 6.919 & .000 \\
\cline { 2 - 4 } & ROA & -3.025 & .004 \\
\cline { 2 - 4 } \multicolumn{1}{l}{ CR } & -2.122 & .039 \\
\hline
\end{tabular}

Sumber: Output SPSS Ver.25, 2020

\section{Koefisien Determinasi $\left(\mathbf{R}^{\mathbf{2}}\right)$}

Selanjutnya untuk membuktikan besaran pengaruh variabel bebas terhadap variabel terikat, maka dapat ditunjukkan dalam pengujian koefisen determinasi

Tabel 9. Hasil Koefisien Determinasi $\mathrm{r}^{2}$

\begin{tabular}{cc} 
Tabel 9. Hasil Koefisien Determinasi $\mathrm{r}^{2}$ \\
\hline $\mathrm{R}$ & $\mathrm{R}$ Square \\
\hline .212 \\
\hline Sumber: Output SPSS Ver.25, 2020
\end{tabular}

Sumber: Output SPSS Ver.25, 2020

Hasil olahan SPSS pada tabel 9 menunjukan bahwa uji koefisien determinasi $\left(R^{2}\right)$ sebesar 0.460 atau $46 \%$ yang berarti bahwa hubungan antar variabel independen yaitu ROA dan CR terhadap variabel dependen yaitu DER memiliki hubungan yang dalam kategori sedang. Nilai adjusted $\mathrm{R}$ square sebesar 0.212 atau $21,20 \%$. Hal ini mengartikan bahwa DER (Y) dapat dijelaskan oleh ROA $\left(\mathrm{X}_{1}\right)$ dan $\mathrm{CR}\left(\mathrm{X}_{2}\right)$, sedangkan selebihnya dijelaskan oleh faktor-faktor lain yang mempengaruhi Struktur Modal (DER) yang berada diluar model penelitian.

Kontribusi pengaruh antara variabel independen dengan variabel dependen dapat dilihat pada pengaruh ROA terhadap DER dengan nilai kontribusi $21,2 \%$ diperoleh dari nilai koefisien kolerasi ROA terhadap DER sebesar -0.369 dan nilai Standardized Coefficients sebesar -0.393, pengaruh CR terhadap DER hanya sebesar 14,5 \% diakibatkan karena nilai koefisien kolerasi CR terhadap DER sebesar -0.241 dan nilai Standardized Coefficients sebesar -0.276 dalam permodelan regresi yaitu sebesar $6,7 \%$.

Hasil tersebut dapat ditunjukkan pada tabel berikut:

Tabel 10. Kontribusi variabel

\begin{tabular}{|c|c|c|c|}
\hline $\begin{array}{c}\text { Varia- } \\
\text { bel }\end{array}$ & $\begin{array}{c}\text { Koefisien } \\
\text { Korelasi }\end{array}$ & $\rightarrow \quad \begin{array}{c}\text { Standard- } \\
\text { ized } \\
\text { Coefficie } \\
n t s\end{array}$ & $\begin{array}{c}\text { Nilai } \\
\text { kontribus } \\
\text { i }\end{array}$ \\
\hline ROA & $-0,369$ & $-0,393$ & $=0,211$ \\
\hline CR & $-0,241$ & $-0,276$ & $=0,001$ \\
\hline \multicolumn{3}{|c|}{$\begin{array}{r}\text { Total besaran pengaruh ( } \mathrm{R} \\
\text { square) }\end{array}$} & $=0,212$ \\
\hline
\end{tabular}

Sumber: Output SPSS Ver.25, 2020 


\section{Pengaruh Profitabilitas Terhadap Struktur Modal}

Hasil analisis statistik untuk hipotesis pertama menunjukkan bahwa variabel profitabilitas dengan nilai $t$-hit $-3.025<t_{\text {tab }}$ 2.012 dengan nilai signifikansi sebesar 0,004 lebih kecil dari 0,05. Sehingga variabel profitabilitas tidak memiliki kontribusi terhadap struktur modal. Nilai $\mathrm{t}_{\text {-hit }}$ yang negatif menunjukkan bahwa profitabilitas mempunyai hubungan tidak searah dengan struktur modal, yaitu variabel profitabilitas berpengaruh negatif dan signifikan terhadap struktur modal.

Hal ini berarti bahwa hipotesis pertama diterima. Artinya apabila terjadi peningkatan pada nilai profitabilitas, maka struktur modal perusahaan semakin menurun. Hasil penelitian ini konsisten dengan penelitian yang dilakukan (Wahyuni \& Suryantini, 2014; Siahaan dkk., 2020) dalam penelitiannya menemukan profitabilitas berpengaruh negatif dan signifikan terhadap struktur modal perusahaan. Artinya semakin besar profitabilitas perusahaan struktur modal akan menurun, maka jika profitabilitas perusahaan meningkat, penggunaan utang perusahaan akan menurun. Ketidak sesuaian temuan ditunjukkan pada studi yang dilakukan Nugroho (2014) bahwa profitabilitas berpengaruh positif signifikan terhadap struktur modal. Saputri dkk., (2020) bahwa profitabilitas memberikan efek positif namun tidak signifikan dalam meningkatkan struktur modal.

\section{Pengaruh Likuiditas Terhadap Struktur Modal}

Hasil analisis statistik untuk hipotesis kedua menunjukkan bahwa variabel likuiditas dengan nilai $t_{\text {hit }}-2.122<\mathrm{t}_{\text {tab }} 2.010$ dengan nilai signifikansi sebesar 0,039 kecil dari 0,05. Sehingga variabel likuiditas tidak memiliki kontribusi terhadap struktur modal. Nilai $t$ negatif menunjukkan bahwa likuiditas mempunyai hubungan tidak searah dengan struktur modal, yaitu variabel likuiditas berpengaruh negatif signifikan terhadap struktur modal.

Hal ini berarti bahwa hipotesis kedua diterima. Artinya Likuiditas yang semakin tinggi akan menurunkan struktur modal perusahaan yang berarti perusahaan dengan likuiditas tinggi memiliki kemampuan membayar utang jangka pendeknya yang cenderung menurunkan utang sehingga struktur modal menjadi lebih kecil. Hasil penelitian ini sesuai dengan penelitian yang dilakukan oleh Deviani (2018); Saputri dkk., (2020) bahwa likuiditas berpengaruh negatif dan signifikan terhadap struktur modal. Kemudian studi ini menolak temuan Irdiana, (2016); Bhawa, (2015) bahwa likuiditas memeberikan efek positif signifikan pada struktur modal.

\section{KESIMPULAN DAN SARAN}

Penelitian ini memberikan bukti bahwa profitabilitas berpengaruh negatif dan signifikan terhadap struktur modal, Hal ini berarti bahwa hipotesis pertama diterima. Artinya apabila terjadi peningkatan pada nilai profitabilitas, maka semakin menurun struktur modal perusahaan. semakin besar profitabilitas perusahaan struktur modal akan menurun, maka jika profitabilitas perusahaan meningkat, penggunaan utangnya akan menurun.

Likuiditas berpengaruh negatif dan signifikan terhadap struktur modal, Hal ini berarti bahwa hipotesis kedua diterima. Artinya Likuiditas yang semakin tinggi akan menurunkan struktur modal perusahaan yang berarti perusahaan dengan likuiditas tinggi memiliki kemampuan membayar utang jangka pendeknya yang cenderung menurunkan utang sehingga struktur modal menjadi lebih kecil.

Studi ini memberikan rekomendasi bagi penelitian selanjutnya diharapkan untuk menambah jangka waktu pengamatan yang lebih panjang karena semakin lama waktu pengamatan maka semakin besar kesempatan untuk melakukan pengamatan yang akurat.

Peneliti selanjutnya diharapkan mempertimbangkan menggunakan variabel ukuran perusahaan. Hasil penelitian ini masih memiliki banyak keterbatasan, sehingga sangat diharapkan untuk peneliti lanjutan menambah variabel-variabel lain yang dapat mempengaruhi profitabilitas agar memperluas area penelitian. 


\section{REFERENSI}

Darman, D. (2019). Pengaruh Ukuran Perusahaan, Risiko Bisnis Terhadap Struktur Modal Pada Perusahaan Properti Dan Real Estate Yang Terdaftar Di Bei Pada TAHUN 20132017. Eko dan Bisnis: Riau Economic and Business Review, 10(2), 215-224.

Deviani, M. Y., dan Sudjarni, L. K. (2018). Pengaruh Tingkat Pertumbuhan, Struktur Aktiva, Profitabilitas, dan Likuiditas terhadap Struktur Modal Perusahaan Pertambangan di BEI. EJurnal Manajemen, 7(3),

Farida, L. (2016). Pengaruh Profitabilitas dan Likuiditas Terhadap Struktur Modal Perusahaan Asuransi (Yang Terdaftar di Bursa Efek Indonesia (BEI) Periode 2012-2014) (Doctoral dissertation, Riau University).

Harris, M. I., Sjahruddin, H., \& Themba, O. S. (2020). Kontribusi Rasio Aktivitas dan Ukuran Perusahaan pada Rentabilitas PT. Telekomunikasi Indonesia (Persero), Tbk. Jurnal SEKURITAS (Saham, Ekonomi, Keuangan dan Investasi), 3(3), 219229.

Hermuningsih, S. (2013). Pengaruh profitabilitas, growth opportunity, struktur modal terhadap nilai perusahaan pada perusahaan publik di Indonesia. Buletin ekonomi moneter dan perbankan, 16(2), 127148.

Kasmir. (2017). Analisis Laporan Keuangan. Jakarta: PT Rajagrafindo Persada.

Lorenza, D., Kadir, M. A., \& Sjahruddin, H. (2020). Pengaruh Struktur Modal Dan Ukuran Perusahaan Terhadap Profitabilitas Pada Perusahaan Otomotif Yang Terdaftar Di BEI. Jurnal Ekonomi Manajemen, 6(1), 1320.

Liem, J. H., Murhadi, W. R., dan Sutejo, B. S. (2013). Faktor-faktor yang
Mempengaruhi Struktur Modal pada Industri Consumer Goods yang terdaftar di BEI periode 20072011. Calyptra, 2(1), 1-11.

Noviana, J. (2017). Pengaruh profitabilitas terhadap kebijakan dividen melalui struktur modal (studi pada perusahaan manufaktur yang terdaftar di BEI ahun 2015).

Nugroho, N. C. (2014). Analisis Pengaruh Profitabilitas, Pertumbuhan Penjualan, Ukuran Perusahaan dan Umur Perusahaan terhadap Struktur Modal Usaha Mikro Kecil dan Menengah Kerajinan Kuningan di Kabupaten Pati. Management Analysis Journal, 3(2). 1222-1254.

Priyonoto, B., Wibowo, A. S., dan Diarsyad, M. I. (2018). Pengaruh current ratio, debt to equity ratio, return on equity terhadap return saham pada perusahaan consumer goods yang go public di bursa efek indonesia tahun 2013-2016. FEB UPR.

Purnamasari, I. (2018). Pengaruh Profitabilitas, Likuiditas, Leverage, dan Kebijakan Deviden terhadap nilai perusahaan: Studi Pada Jakarta Islamic Index Tahun 20122016 (Doctoral dissertation, Universitas Islam Negeri Maulana Malik Ibrahim).

Santoso, Y., dan Priantinah, D. (2016). Pengaruh Profitabilitas, Ukuran Perusahaan, Struktur Aktiva, Likuiditas dan Growth Opportunity terhadap Struktur Modal Perusahaan. Jurnal Profita: Kajian Ilmu Akuntansi, 4(4).

Sari, D. V., dan Haryanto, A. M. (2013). Pengaruh Profitabilitas, Pertumbuhan Aset, Ukuran Perusahaan, Struktur Aktiva Dan Likuiditas Terhadap Struktur Modal Pada Perusahaan Manufaktur Di Bursa Efek. 
Saputri, I. P., Nurlaela, S., \& Titisari, K. H. (2020). Profitabilitas, Likuiditas, Struktur Aktiva, Ukuran Perusahaan, Pertumbuhan Penjualan Dan Struktur Modal Perusahaan Restoran, Hotel \& Pariwisata. Jurnal Penelitian Ekonomi dan Akuntansi. 5(1), 91107.

Siahaan, N. T., Asmapane, S., \& Lahjie, A. A. (2020). Pengaruh Profitabilitas dan Likuiditas serta Ukuran Perusahaan Terhadap Struktur Modal Perusahaan Pariwisata, Perhotelan dan Restoran Yang Terdaftar Di Bursa Efek Indonesia. Jurnal Ilmu Akuntansi Mulawarman (JIAM), 4(4). 